\title{
Nature of the distributional boundary of Fucus serratus on the north shore of Spain
}

\author{
Julio Arrontes \\ Laboratorio de Ecología, Departamento de Biologia de Organismos y Sistemas, Universidad de Oviedo, E-33005 Oviedo, Spain
}

\begin{abstract}
The distribution of Fucus serratus has a sharp boundary in northern Spain. F. serratus dominates the mid-intertidal region west of Novellana. Asturias, but is absent further east. In a short transition zone, F. serratus is abundant within patches. The causes underlying this pattern were investigated by experimental transplants of $F$. serratus to locations in the transition zone and outside its normal range. Plants moved outside the normal range had similar growth and reproductive rates to those transplanted to the transition zone and within the zone of abundance. F. serratus recruited at sites outside the normal boundary, apparently from transplanted thalli. Temperature affected the growth rate of embryos of $F$. serratus in laboratory experiments. Though high summer temperatures may be responsible for the lack of $F$. serratus in the inner part of the Bay of Biscay, temperature alone cannot explain the observed limit of distribution. Other factors such as limited dispersal ability and interspecific competition with other macroalgae might also be important in setting the boundary for F. serratus in northern Spain.
\end{abstract}

\section{INTRODUCTION}

The geographical distribution of marine algae has frequently been related to the influence of physical factors (e.g. Dring 1982, van den Hoek 1982, Lüning 1990). The limits of distribution are often set by the effect of critical temperatures on survival, reproduction and growth of plants (van den Hoek 1982). Much experimental work has shown the relationship between distribution and tolerance to temperature in algae (e.g. Norton 1977a, Yarish et al. 1987, Breeman 1988. Cambridge et al. 1990). In addition to temperature, photoperiod (Breeman 1988), longitudinal barriers (van den Hoek 1975, 1987) and salinity (Bird \& McLachlan 1986, Russell 1987) have been invoked to explain patterns of distribution.

In addition to physical factors, biological factors are recognized as acting on the distribution of macroalgae at small scales. Their role has been much less frequently studied, though herbivory can be important in explaining the patterns of algal abundance in different geographical areas (Lubchenco 1980. Hay 1981, Gaines \& Lubchenco 1982).

A conspicuous change in the composition of marine algae has been described along the shores of northern
Spain. Important differences exist in the species composition between northwestern Spain (facing the open Atlantic waters) and the Basque coast (in the inner part of the Bay of Biscay) (e.g. Fischer-Piette 1957, Anadón \& Niell 1981, Anadón 1983, Lüning 1990). In his study on phytogeographic provinces, van den Hoek (1975) grouped the flora of NW Spain with the floras of NW Brittany and Clare Island, and the flora of the Basque coast with the flora of Morocco. Several species of large brown algae reach their limit of distribution in a middle zone in north Spain (including Fucus serratus, Laminaria ochroleuca, Himanthalia elongata and others) (Anadón \& Niell 1981, Anadón 1983, Lüning 1990). Their pattern of distribution has been frequently explained by the lack of rocky substratum from the Loire to the Basque coast and locally high temperature during summer in the inner part of the bay (Lüning 1990). Summer upwelling conditions would produce temperature ranges suitable for these macroalgae, permitting their reappearance on the west shore of nor thern Spain. Although the distributional boundaries are not exactly coincident for all these species, they lie in approximately the same part of the shore. Past evidence suggests, however, that the limits of distribtion of these species have moved considerably during this century (Fischer-Piette 1957). 
Among the species displaying an unequal distribution along the shore of N Spain, Fucus serratus exhibits a sharp decline in abundance from west to east. It is abundant in NW Spain, where it often dominates the space in mid and lower tidal levels, but is absent from the Basque coast. F. serratus is a species widely distributed on the Atlantic shores of Europe and is locally abundant in Nova Scotia (Canada). Its southern distributional boundary on the European shores lies in northern Portugal (Pazó \& Niell 1977, Lüning 1990). If its distribution is primarily determined by temperature, then it can be assumed that high temperatures are important in setting the distribution boundary on the shore of N Spain (see Breeman 1988).

Several oceanographic features with potential influence on the dispersal, growth and survival of macroalgae have been described for the Spanish shore of the bay of Biscay. Coastal currents are W-E during winter but inverse, $\mathrm{E}-\mathrm{W}$, during summer. During summer, surface waters are warmer towards the inner part of the bay (US Naval Oceanographic Office 1967, Maillard 1986). The difference in temperature between the inner and outer part can be as large as $3^{\circ} \mathrm{C}$. This difference can be temporarily increased in some zones due to upwelling conditions near the shore during summer. Underwater currents, driven by northeasterly winds, are responsible for the elevation of cold water (Botas et al. 1990). Upwelling conditions are more persistent and intense towards the western part of the Spanish north shore of the bay. During winter, minimum seawater temperature is between 10 and $11^{\circ} \mathrm{C}$. Maximum temperature in summer is 19 to $20^{\circ} \mathrm{C}$ for most of the shore and 21 and occasionally $22^{\circ} \mathrm{C}$ in the inner part of the bay. In the littoral zone of those parts of the shore under upwelling conditions, temperature is expected to be lower and concentration of inorganic nutrients (e.g. nitrate, phosphate) to be higher than those in oceanic waters or in adjacent, non-upwelled coastal waters. During winter, oceanographic conditions are the same for the entire coast (Maillard 1986, SATMER 1990a)

In this paper, I explore the factors with putative influence on the distribution of Fucus serratus in northern Spain. Specifically, I investigate the ability of transplanted thalli of $F$. serratus to grow and develop reproductive structures in localities outside its range of distribution. It was hypothesized that the environment of the places where the species is absent negatively influences growth and/or reproduction and so prevents the spread of F. serratus. In addition to the transplant experiment, I present information on the growth and reproduction of the species in its natural environment and a laboratory experiment on the effect of temperature on the growth of $F$. serratus embryos.

\section{MATERIAL AND METHODS}

A survey, between $6^{\circ}$ and $7^{\circ} \mathrm{W}$, was made along the coast of Spain to detect the exact location of the distributional boundary of Fucus serratus. Field experiments were made at 3 localities, Oleiros $\left(43^{\circ} 34^{\prime} \mathrm{N}\right.$, $6^{\circ} 12^{\prime} \mathrm{W}$ ), Campiello (433 $33^{\prime} \mathrm{N}, 6^{\circ} 24^{\prime} \mathrm{W}$ ) and Torbas $\left(43^{\circ} 33^{\prime} \mathrm{N}, 6^{\circ} 47^{\prime} \mathrm{W}\right)$ (Fig. 1). All 3 stations are rock platforms under steep cliffs exposed to moderate wave action. The substratum is formed by quartzite and slate. Oleiros is outside the normal range of distribution of Fucus serratus, Campiello is in a transition zone, where F. serratus occurs in patches, while at Torbas $F$. serratus is abundant. Intertidal zonation was studied at Torbas and Oleiros by making a transect perpendicular to the shoreline from $0.5 \mathrm{~m}$ to $2.5 \mathrm{~m}$ above the lowest tidal level. At regular intervals $(2 \mathrm{~m}$ at Oleiros, $3 \mathrm{~m}$ at Torbas), percentage cover of macroalgae was estimated in 3 replicate $1 \mathrm{~m}^{2}$ quadrats with 100 regularly spaced points.

At the 3 localities, temperature and concentration of nitrate and nitrite were measured at monthly or fortnightly intervals, coinciding with spring tides, from January 1990 to January 1991. At each locality, 4 replicate samples of seawater were collected at each of 4 randomly chosen sites. Nitrate and nitrite were analysed using an Autoanalyser Technicon AAII. Chemical analysis were made using the methods

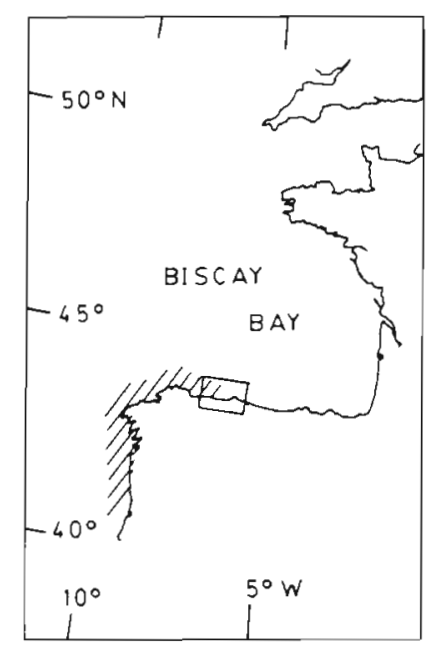

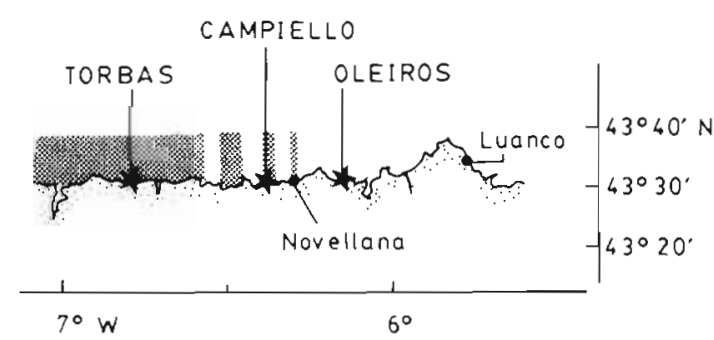

Fig. 1 Study sites. The shaded area represents the zone where Fucus serratus is present. Discontinuous shading represents the transition zone 
described in Grashoff (1983). No other nutrients were analysed since they are considered less important for the primary production of macroalgae (DeBoer 1981, Lobban et al. 1985).

To study the seasonal variation in biomass and reproductive status of Fucus serratus at Torbas and Campiello, 5 canopy-forming plants were collected at random from 4 sites at monthly intervals. Reproductive allocation of each plant was calculated as percentage of dry weight represented by receptacles. Differences in size between canopy plants of $F$. serratus in Torbas and Campiello were estimated from 2 random samples of 65 plants taken at each locality in May 1990 (5 sites $\times 13$ plants site ${ }^{-1}$ ).

Growth of Fucus serratus under natural conditions was investigated at 3 sites at Torbas and Campiello. Plants of 2 size categories were chosen, individuals less than $20 \mathrm{~cm}$ long (which did not form part of the canopy) and large, canopy-forming, specimens. Fifteen plants of each size group were individually marked at each site by tying fishing line with coloured beads to their stipes. Length of the plants was recorded at monthly intervals from May to November 1990.

Vegetative thalli 15 to $22 \mathrm{~cm}$ long were chosen for the transplantation experiment. Pieces of rocks with attached algae were chipped off with a chisel and transported to the laboratory where they were individually marked (as above) and measured. At the destination locality, stones with the Fucus serratus plants attached were cemented to the rock substratum in groups of 5 plants, within an approximate area of $30 \times$ $30 \mathrm{~cm}$. Three groups were set at each of 3 randomly chosen sites.

The experimental design consisted of reverse transplants between Torbas and Campiello (within abundance and transition zones) and from Torbas to Oleiros (outside the zone). I predicted that plants moved outside their normal range of distribution would suffer higher mortality and slower growth rates than those moved within their normal range. To control for the effects of the transplanting process per se, 45 plants collected at Torbas and 45 collected at Campiello were moved to different sites at Torbas and Campiello respectively. Length of thalli was measured at monthly or fornightly intervals and the number of receptacles per plant recorded. As an estimate of bushiness, the number of tips per plant was counted at 3 different times. Although the experiment was designed to run for 6 mo, from April to October 1990, additional measurements were made in November 1990 and January, May and September-October 1991.

The ability of Fucus serratus to recruit in zones where it was not naturally present was investigated in the 3 localities by scraping clean quadrats of $60 \times 60 \mathrm{~cm}$ size. Three sites were chosen at Torbas and Oleiros and 4 at Campiello. At each site, 4 replicated quadrats were scraped at each of 2 tidal levels. At Oleiros, the quadrats were cleared in the zones dominated by Fucus vesiculosus (high tidal level) and Bifurcaria bifurcata (low tidal level). At Campiello, in 2 sites the quadrats were scraped in the zones dominated by $F$. vesiculosusus and $B$. bifurcata, while in the remaining 2 the experimental surfaces were in zones of $F$. vesiculosus (high level) and F. serratus (low level). At Torbas, the quadrats were in the zones dominated by $F$. vesiculosus and $F$. serratus. The experimental surfaces were left to recover for $6 \mathrm{mo}$. Then, abundance of algae in each was estimated as percent cover of the algae in two $20 \times 20 \mathrm{~cm}$ quadrats with 100 regularly placed points.

The effect of temperature on the growth rate of embryos was tested in the laboratory. Mature receptacles were excised from plants collected at Torbas. Release of gametes and fertilization was induced following the procedure described in McLachlan et al. (1971). Between 25 and 40 zygotes were placed in $55 \times 15 \mathrm{~mm}$ disposable petri dishes with $15 \mathrm{ml}$ of medium. Culture medium consisted of half-strength Provasoli medium (PES) (McLachlan 1973). The medium was changed weekly. The embryos were incubated at $12,15,18$ and $21^{\circ} \mathrm{C}$, with a light:dark cycle of $12: 12 \mathrm{~h}$. Photon flux density was $60 \mu \mathrm{E} \mathrm{m} \mathrm{m}^{-2}$ $s^{-1}$. Four replicate dishes were incubated at each temperature. Twenty-six days after fertilization, length of 5 randomly chosen embryos was measured in each dish. Only the pigmented part of the embryos was measured.

\section{RESULTS}

The disappearance of Fucus serratus occurs in a short stretch of the coast of about $30 \mathrm{~km}$. The survey of the coast indicated that $F$. serratus is patchily distributed within the transition zone; although absent from many locations, it monopolizes the substratum at others. It is the size of the patches and not the density of $F$. serratus which defines the abundance of the alga in the localities of the transition zone. In localities at the limits of distribution, only a few small patches were found. Although plants were smaller in these patches (see below), the density and appearance of the plants did not differ greatly from stands found within the zone of abundance. East of Novellana (in Luanco), an isolated population of $F$. serratus was found which consisted of a conspicuous single patch of $4 \times 8 \mathrm{~m}$ size (see Fig. 1 for localities).

Zonation profiles of abundant species of algae at Torbas and Oleiros are shown in Fig. 2. The obvious 
COVER $(\%)$

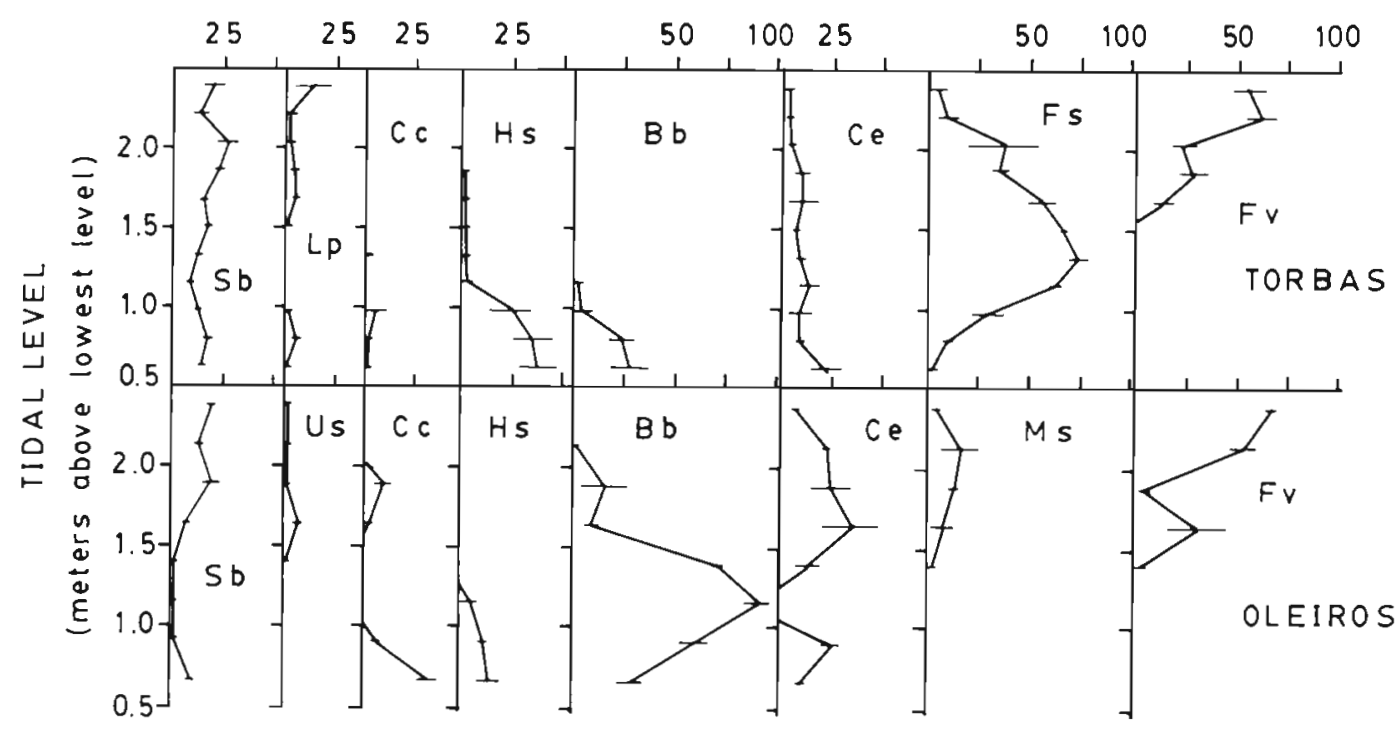

Fig. 2. Zonation profiles of Torbas and Oleiros. Means $\pm \mathrm{SE}$. Fv = Fucus vesiculosus, Fs = Fucus serratus, Ms = Mastocarpus stellatus, $\mathrm{Ce}=$ Corallina elongata, $\mathrm{Bb}=$ Bifurcaria bifurcata, $\mathrm{Hs}=$ Halopteris scoparia, $\mathrm{Cc}=$ Chondrus crispus, Lp $=$ Laurencia pinnatifida, Us = Ulva sp., $\mathrm{Sb}=$ substratum

difference between them is the absence of Fucus serratus in Oleiros. At this locality, the tidal level occupied in Torbas by F. serratus is occupied by F. vesiculosus, Corallina elongata, Bifurcaria bifurcata and Mastocarpus stellatus. Patterns of zonation at Campiello (not presented here) vary, depending on whether $F$. serratus is present. Where $F$. serratus is present, zonation is similar to that of Torbas, and where it is absent, the shore looks like that at Oleiros.

Temperatures were similar at all 3 localities studied (Fig. 3). They had a minimum temperature of $12^{\circ} \mathrm{C}$. The maximum summer temperature was $18.5^{\circ} \mathrm{C}$ at Torbas and Campiello and $19{ }^{\circ} \mathrm{C}$ at Oleiros (Fig. 3).

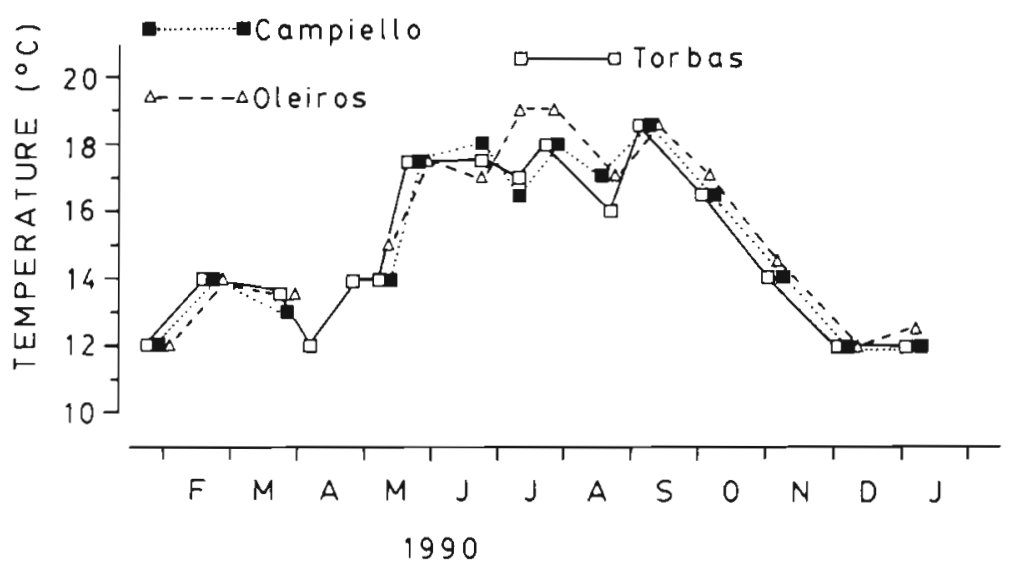

Fig. 3. Temperature of seawater at the study sites
The concentration of nitrate and nitrite in the seawater at the sampling localities followed a seasonal cycle (Fig. 4). At all 3 localities, concentration was highest in January 1991 (5 to $6 \mu \mathrm{mol} \mathrm{l}^{-1}$ ) and lowest from May to September. Although the concentration of nitrate during summer was below $0.5 \mu \mathrm{mol} \mathrm{l}^{-1}$ at the 3 localities, Torbas consistently showed significantly higher concentrations than those found at either Oleiros or Campiello (Table 1). However, the concentration did not only vary among the localities, but also among sites within each locality and date (Table 1).

The biomass of individual Fucus serratus thalli varied with the seasons at Torbas and Campiello (Fig. 5A). Biomass was highest during summer, from June to September, and was lowest in January-February (Fig. 5A). Biomass of plants was consistently greater at Torbas than at Campiello. In May, canopy plants at Torbas were larger than those measured at Campiello (Torbas; mean $=45.15 \mathrm{~cm}$, $\mathrm{SE}=1.62$; Campiello; mean $=29.81 \mathrm{~cm}$, $\mathrm{SE}=1.72$ ) (Table 2).

Although fertile Fucus serratus were found throughout the year, seasonal variations in the percentage of biomass devoted to reproduction existed (Fig 5B). Maximum weight of receptacles per plant was reached in summer $(28 \%$ at Torbas and $26 \%$ in Campiello). From February to August 1990 the percentage of biomass 
Fig. 4. Concentration of dissolved nitrate and nitrite during the study period at the 3 study localities. Inset: rescaled concentrations during summer. Means $\pm \mathrm{SE}$

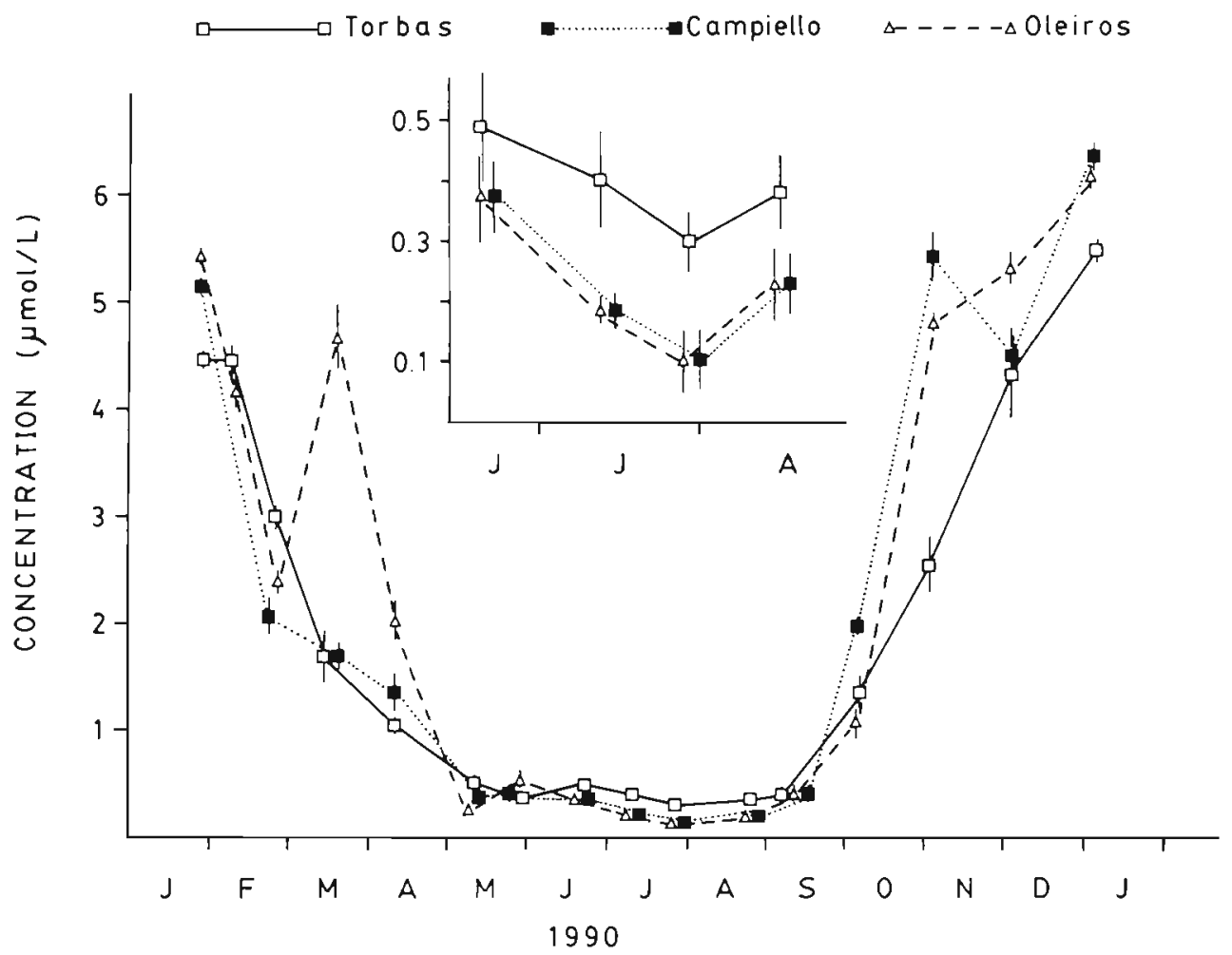

devoted to reproduction was larger at Torbas than at Campiello; however, these differences were not apparent from August 1990 to January 1991.

The growth rate of small plants was similar at all sites at Campiello and Torbas (Fig. 6A). There were no significant differences among localities as calculated from the difference between final and initial size (Table 2). There was, however, evidence of significant variation in growth rate among sites (Table 2). Plants grew continuously from late July to December. No loss

Table 1. Analyses of mean values of nitrate and nitrite concentration at the 3 localities studied during summer. Some samples were contaminated. Therefore 3 replicate samples (instead of 4) were chosen at random from each site and location. Variances were homogeneous (Cochran's test, $p>0.05$ ). Data are in Fig. 4

\begin{tabular}{lrcc}
\hline $\begin{array}{l}\text { ANOVA } \\
\text { Source of variation }\end{array}$ & df & MS & F-ratio \\
\hline Date & 3 & 0.353 & $5.67^{\cdots}$ \\
Location & 2 & 0.452 & $7.27^{\cdots}$ \\
D $\times$ L & 6 & 0.034 & $0.54 \mathrm{~ns}$ \\
Site (D $\times$ L) & 36 & 0.062 & $1.94^{*}$ \\
Residual & 96 & 0.032 & \\
\hline
\end{tabular}

SNK test for differences among locations (= denotes not significantly different, $p<0.05$ )

Torbas $>$ Campiello $=$ Oleiros

$\cdot p<0.05, \cdots p<0.01 ;$ ns: non-significant
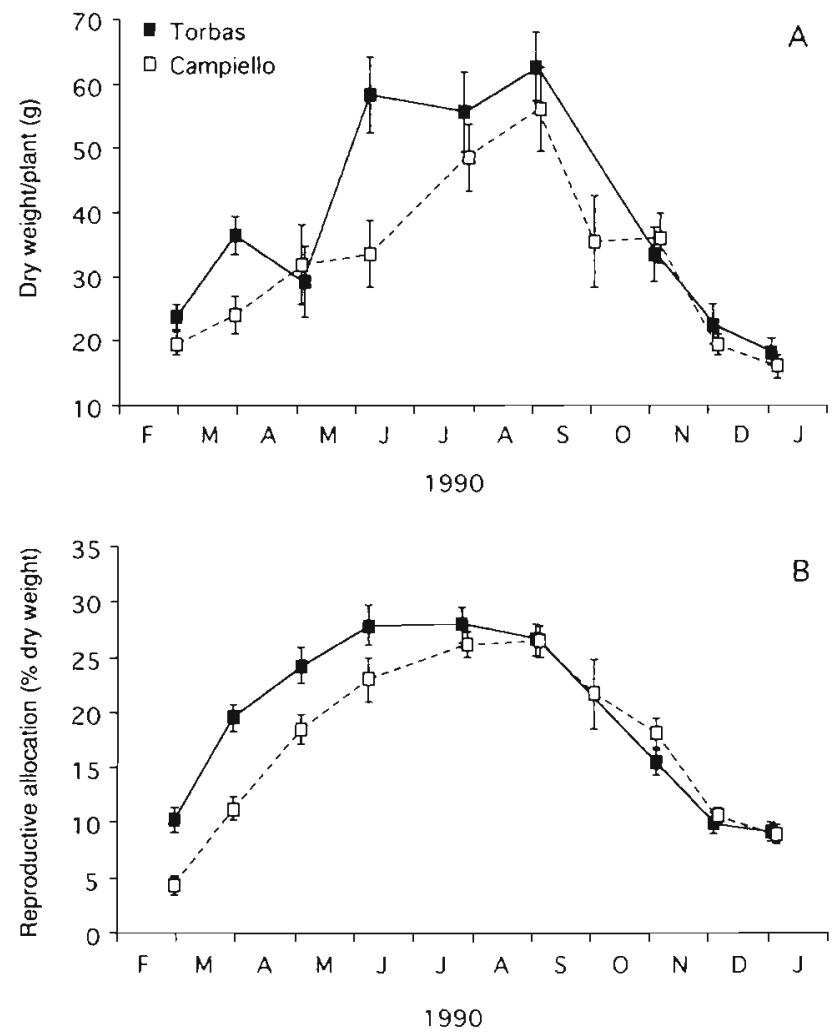

Fig. 5. Fucus serratus. (A) Seasonal variation in weight of individual plants collected at Torbas and Campiello. (B) Seasonal variation in the proportion of biomass devoted to reproduction plants at Torbas and Campiello. Means \pm SE 
Table 2. Fucus serratus. Analyses of (a) mean size of canopy plants and (b) mean increase in size of small plants, in Campiello and Torbas. Variances were homogeneous (Cochran's test, $p>0.05$ ). See text

\begin{tabular}{|c|c|c|c|c|c|c|}
\hline \multirow{2}{*}{$\begin{array}{l}\text { Source of } \\
\text { variation }\end{array}$} & \multicolumn{3}{|c|}{ (a) Size } & \multicolumn{3}{|c|}{ (b) Growth } \\
\hline & $\mathrm{df}$ & MS & $F$ & df & MS & $F$ \\
\hline Location & 1 & 7646.22 & $12.29^{\circ}$ & 1 & 4.02 & $0.11 \mathrm{~ns}$ \\
\hline Site (L) & 8 & 621.97 & $4.05 \cdots$ & 4 & 37.05 & $2.83^{\circ}$ \\
\hline Residual & 120 & 153.49 & & 36 & 13.08 & \\
\hline
\end{tabular}

in bushiness of plants among these treatments (Fig. 9A, Table 4). Differences existed, however, at the smaller scale, as the effect of site was found to be significant.

In all 5 transplants, individuals became fertile, and gametes were apparently viable, though no fertilization experiments were carried out (antherozoids were mobile and oogonia had a spherical 'healthy' aspect). There were, however, significant differences in the number of reproductive

of biomass was detected. In contrast, 2 distinct periods of growth and loss of biomass existed in canopy plants (38 to $44 \mathrm{~cm}$ long; Fig. 6B). Plants grew from May (date of marking) to early October. Loss of biomass occurred between October and December (end of the experiment). Plants longer than $50 \mathrm{~cm}$ at Torbas showed no net increase in size over the period of the experiment (Fig. 6B).

At the end of the experiment (October 1990) and $1 \mathrm{yr}$ later (October 1991), significant differences between transplants existed in the number of remaining plants (Fig. 7) $\left(\chi_{4}^{2}=9.51, p<0.05\right.$ and $\chi_{4}^{2}=14.68, p<0.01$, respectively). The greatest number of plants was lost at Oleiros, and the smallest in the 'autotransplant' at Torbas. No significant differences in growth existed between plants of the different transplants (Fig. 8, Table 3). Even after 17 mo from the begining of the experiment, no differences existed. Growth was fast from April (at the start of the experiment) to early September. There was no evidence of artifactual effects of moving plants. The sizes of plants collected at Torbas or Campiello and moved to Campiello and Torbas, respectively, were not significantly different to those of plants transplanted within the same locality (Fig. 8). Similarly, there were no significant differences structures per plant (Table 4a, Fig. 9B). Plants moved to Oleiros from Torbas developed the largest number of reproductive tips. No differences existed between specimens of all other transplants (Table $4 \mathrm{~b}$ ). The effect of site was, again, significant. Recruitment of young Fucus serratus has been observed among the transplanted specimens in those sites where F. serratus was absent (Oleiros and some sites at Campiello). At Oleiros, in October 1991, more than 100 small $F$. serratus were found around the transplanted specimens (mean size = $13.8 \mathrm{~cm}, \mathrm{SE}=0.97, \mathrm{n}=24$ ). Some of the new plants have subsequently developed receptacles (pers, obs.). Exhaustive exploration of the rock platform at Oleiros failed to reveal newly recruited $F$. serratus other than those close to the transplants.

Six months after clearing, Fucus serratus recolonized the scraped areas in the F. serratus zone. No F. serratus grew in quadrats cleared in the areas dominated by $F$. vesiculosus or Bifurcaria bifurcata. Differences existed in the rate of recolonization in scraped quadrats high on the shore, in the $F$. vesiculosus area. It was slower at Oleiros than at Campiello or Torbas. Almost no plants of $B$. bifurcata grew in the scraped quadrats in the area dominated by this alga. Most of the algae colonizing the Bifurcaria quadrats were ephemerals.

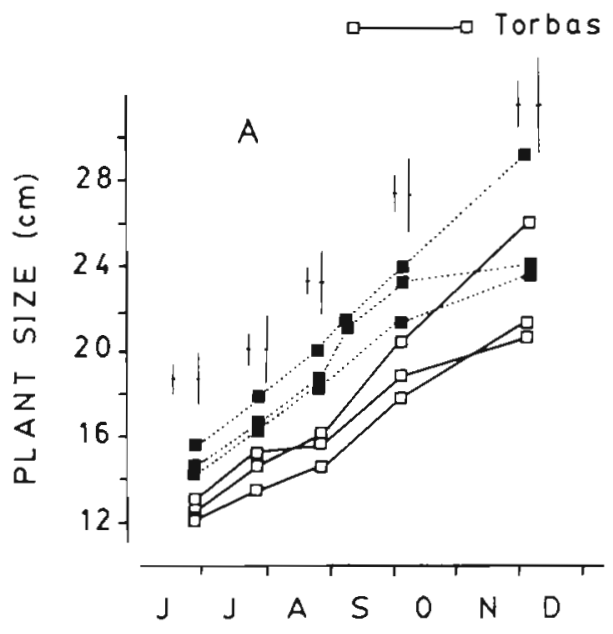

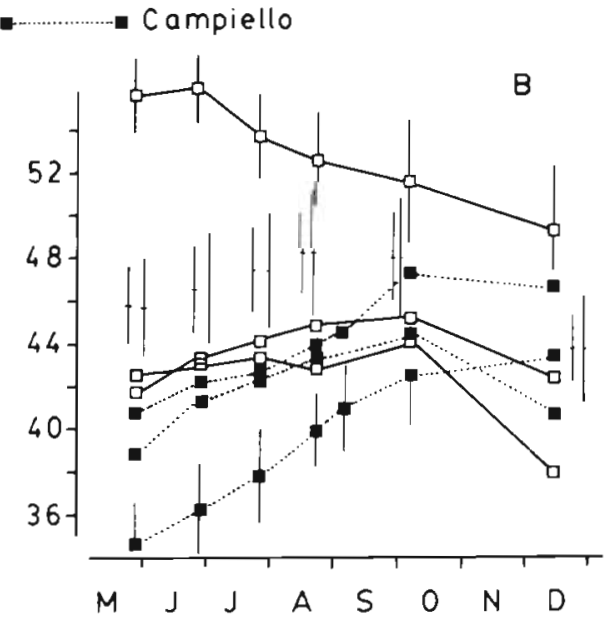

1990
Fig. 6. Fucus serratus. Variation in size specimens marked at Torbas and Campiello. (A) Small plants (B) Canopy-forming specimens. Means \pm SE. Smallest and largest SE bars are shown where no clear graphical presentation was possible 
Fig. 7. Fucus serratus. Number of remaining transplanted specimens. Means $\pm \mathrm{SE}$

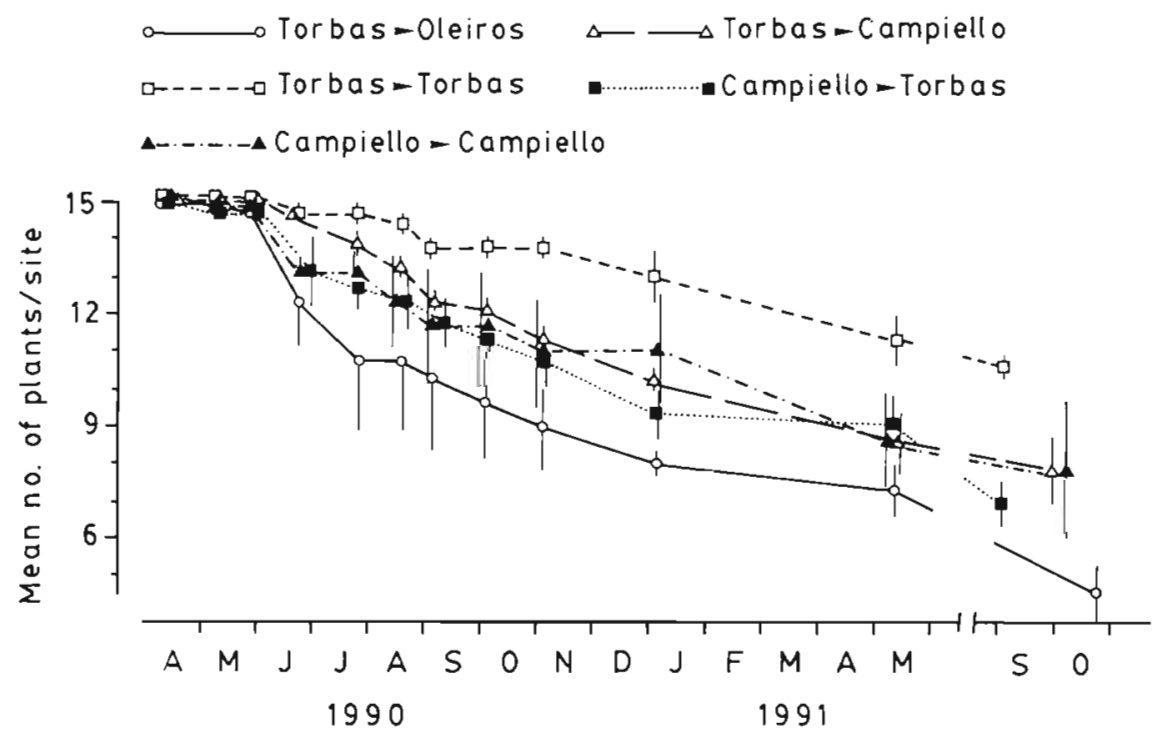

\section{DISCUSSION}

growth of Fucus serratus embryos (Fig. 10. Table 5). Maximum growth was recorded at $18{ }^{\circ} \mathrm{C}$. Growth of embryos incubated at $21^{\circ} \mathrm{C}$ was identical to that of embryos at $12^{\circ} \mathrm{C}$.

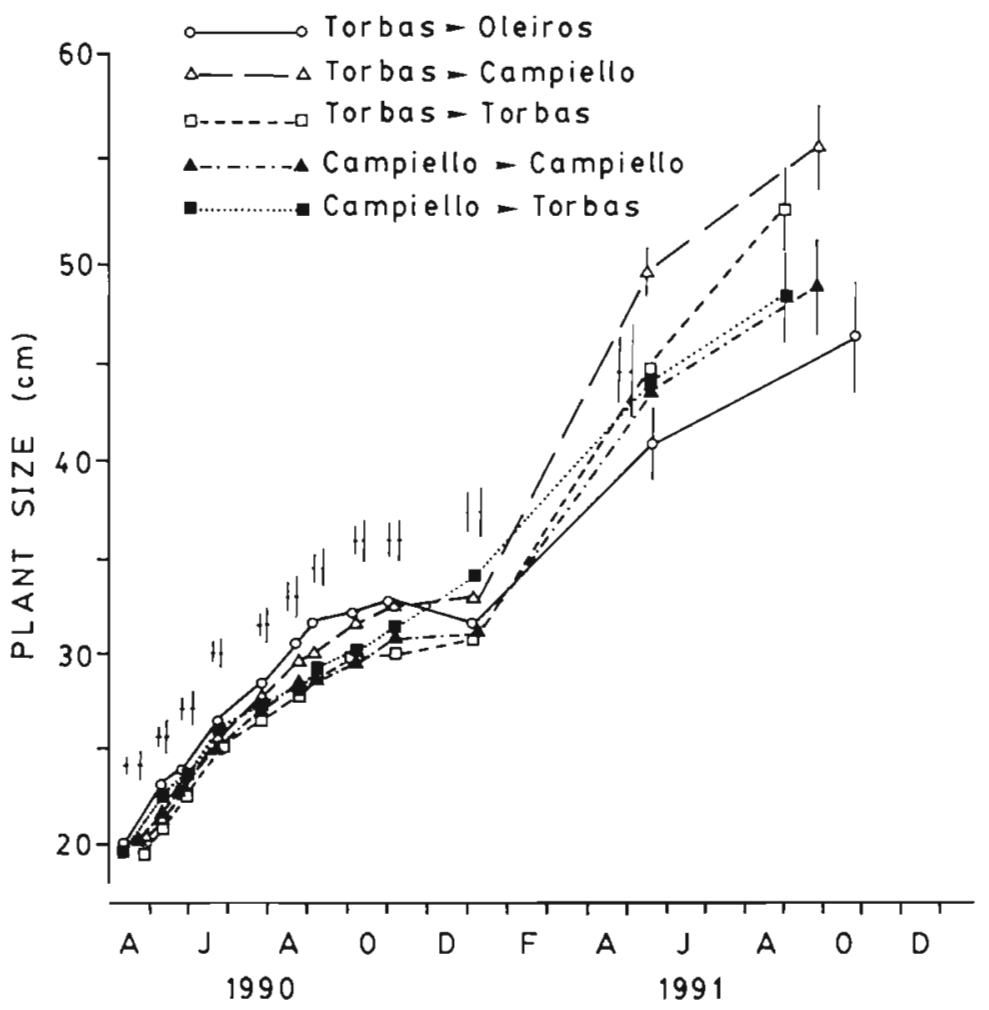

Fig. 8. Fucus serratus. Variation in size of transplanted specimens. Means \pm SE. Error bars as in Fig. 6
Thalli of Fucus serratus transplanted outside the normal range of the species grew and reproduced at similar rates to those transplanted within the distributional limit. New plants, apparently recruited from fertile, transplanted individuals, were found and these too developed reproductive structures. This result suggests that, at least in average years, physical factors alone cannot be invoked to explain the nature of the boundary itself, its location and why the transition zone is so small.

The southern boundaries of many macroalgae in Europe are set by temperatures that are too high in winter and/or summer. High temperatures during winter usually inhibit completion of the life history while high temperatures in summer have often lethal effects (see Breeman 1988 for examples). In the case of the north coast of Spain, marked differences in temperature exist during summer from west to east, but not during winter (US Naval Oceanographic Office 1967, Maillard 1986, SATMER 1990a, b). If temperature is a factor controlling the distribution of Fucus serratus, its influence is most likely to occur during summer. Temperature can be invoked to explain the absence of $F$. serratus in the inner part of the Bay of Biscay, where it commonly reaches $21^{\circ} \mathrm{C}$ or more during summer. The results of the laboratory experiment reported here are consistent with 
Table 3. Fucus serratus. Analyses of mean size of transplanted specimens in (a) October 1990 and (b) September 1991, after 6 and 17 mo, respectively, from the beginning of the experiment. (a) Some experimental plants were lost in some transplants, therefore 10 plants were chosen at random from each transplant and site. The sizes of 2 additional missing plants in 2 sites were estimated from the mean of those sites and transplants, and 2 degrees of freedom substracted from the residual. (b) Five replicated plants were chosen at random. The sizes of 3 missing replicated plants were estimated as above and $3 \mathrm{df}$ substracted from the residual. In both cases, variances were homogeneous (Cochran's test, $p>0.05$ ). Data are in Fig. 8

\begin{tabular}{lrrrrrrr|}
\hline Source of & \multicolumn{3}{c}{ (a) October 1990 } & & \multicolumn{3}{c|}{ (b) September 1991} \\
variation & df & MS & $F$ & & df & MS & $F$ \\
& & & & & & & \\
Transplant & 4 & 25.69 & $0.75 \mathrm{~ns}$ & & 4 & 176.05 & $1.06 \mathrm{~ns}$ \\
Site (T) & 10 & 34.28 & $1.66 \mathrm{~ns}$ & 10 & 166.20 & $1.36 \mathrm{~ns}$ \\
Residual & 133 & 20.66 & & & 57 & 135.13 & \\
ns: non-significant & & & & & & & \\
\hline
\end{tabular}

Craigie 1977, DeBoer 1981, Lobban et al. 1985). Such differences, however, might be important for germlings as their nitrogen supply probably relies exclusively on dissolved nitrogen. In some species, juvenile plants do not appear to store nitrogen (Wheeler \& North 1980).

There is evidence that the conditions in the intertidal zone are far from homogeneous for Fucus serratus. First, the factor 'site' was found to be significant in most of the analyses. This suggests that smallscale events may be important in explaining the distribution of $F$. serratus. Second, in the transition zone, F. serratus usually appears in conspicuous patches. Plants forming these patches, though smaller in length, exhibit a cycle of abundance and reproducthis explanation. At $21{ }^{\circ} \mathrm{C}$, the growth rate of embryos of $F$. serratus was significantly lower than that at 18 and $15{ }^{\circ} \mathrm{C}$. Considering that development of reproductive structures shows a maximum in summer, the effect of temperature on the growth rate of the embryos may be important in explaining the distribution of $F$. serratus on the coast of northern Spain at a large scale. However, differences in maximum temperature among the 3 localities are too small $\left(0.5^{\circ} \mathrm{C}\right)$ to explain the lack of $F$. serratus at the easternmost locality.

The effect of small differences in the concentration of dissolved nitrate and nitrite among the 3 localities during summer is probably irrelevant for large mature plants. Macroalgae can mobilize nitrogen reserves during summer when the availability of nitrogen salts in the seawater is significantly reduced (Chapman \& tion and a growth rate similar to those of plants growing within the normal range of distribution. Few or no plants are found outside the patches. In these localities it is suggested, therefore, that $F$. serratus exists within a mosaic of suitable and unfavourable locations. Such heterogeneity in the local environment may be responsible for the larger number of transplants lost at Oleiros. Plants moved to unfavourable sites would have been lost, while those moved to adequate sites remained and did not grow at different rates to those fixed at Torbas or Campiello.

If Fucus serratus can grow and reproduce beyond its ary must be different from mere physiological incompetence. Two non-exclusive alternate explanations may be: limited dispersal ability; and competition with other macroalgae. distributional boundary, then the nature of this bound-

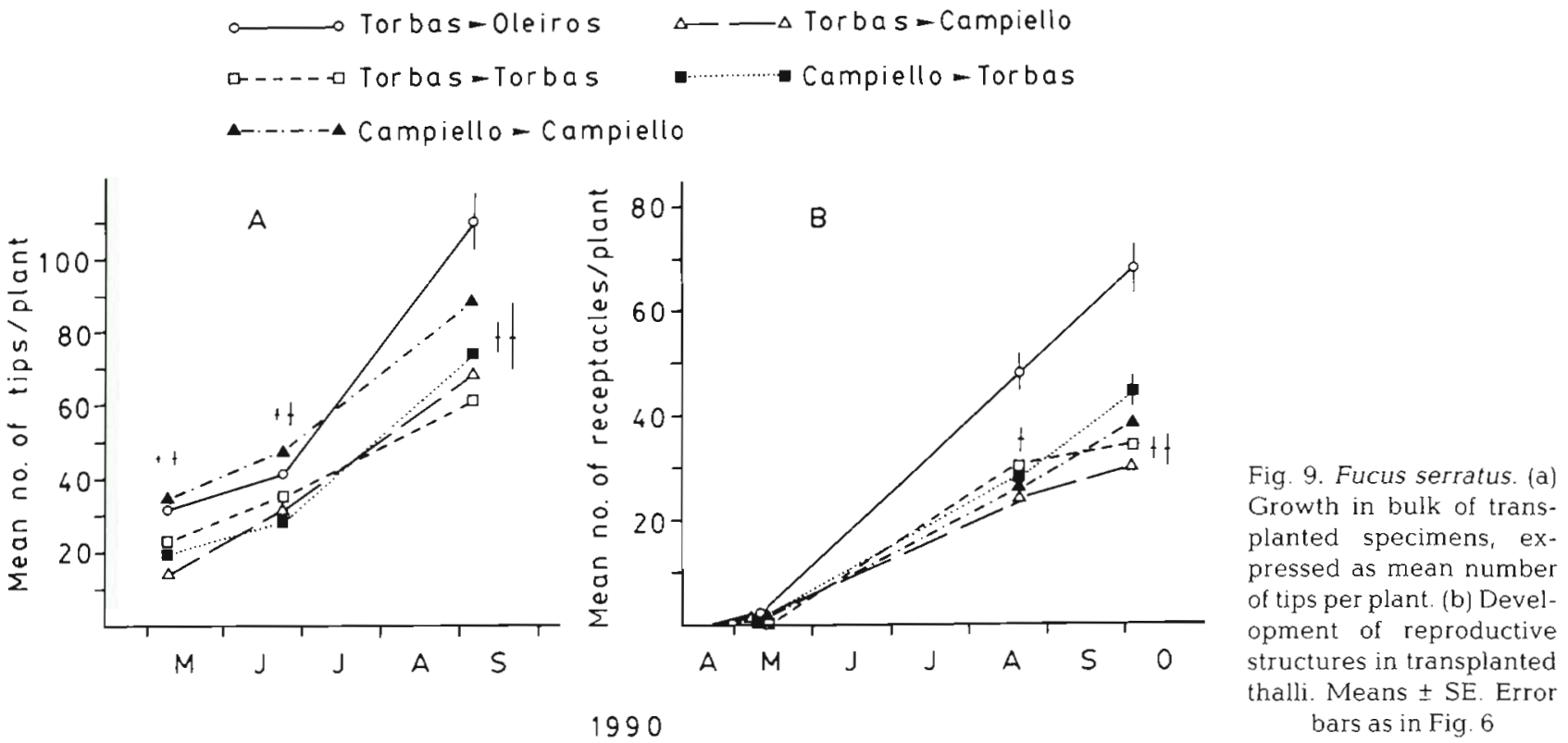


Table 4. Fucus serratus. Analysis of (i) mean number of tips and (ii) mean number of reproductive tips per plant in transplanted specimens. Number of replicated plants used in analysis and df of the residual as in Table 3. Variances were homogeneous (Cochran's test, $p>0.05$ ). Data are in Fig. 9

\begin{tabular}{|lrrrrrr}
\hline $\begin{array}{l}\text { (a) ANOVA } \\
\text { Source of }\end{array}$ & df & \multicolumn{2}{c}{ (i) No. of tips } & \multicolumn{2}{c}{ (ii) Reproductive } \\
variation & & MS & $F$ & \multicolumn{2}{c}{ MS } & F \\
\hline Transplant & 4 & 11033.86 & $3.28 \mathrm{~ns}$ & 6329.16 & $4.67^{\circ}$ \\
Site (T) & 10 & 3361.70 & $2.38^{\circ}$ & 1355.77 & $2.42^{\circ}$ \\
Residual & 133 & 1415.49 & & & 559.33 &
\end{tabular}

(b) SNK tests for differences among transplants in the number of reproductive tips (= denotes not significantly different, $\mathrm{p}<0.05$ ):

Torba $\rightarrow$ Oleiros $>$ Torbas $\rightarrow$ Torbas $=$ Torbas $\rightarrow$ Campiello $=$ Campiello $\rightarrow$

Torbas $=$ Campiello $\rightarrow$ Campiello

$\cdot p<0.05 ;$ ns: non-significant

A low dispersal ability of Fucus serratus was found in this work: (1) F. serratus only recruited on those experimental surfaces which were surrounded by F. serratus (i.e. in which the removed algae were F serratus); (2) new plants found at Oleiros were all within $2.5 \mathrm{~m}$ from the parental plants. In addition, $F$. serratus is a dioecious species and thus, for efficient dispersal, it is necessary that 2 propagules (zygotes) of different sex arrive at the same suitable site and become fertile at the same time, and, of course, that the 2 plants are close enough to allow fertilization.

Considerable evidence exists regarding the limited dispersal of propagules of several macroalgae (Anderson \& North 1966, Dayton 1973, Paine 1979, Chapman 1986; see Santelices 1990 for review). In some cases dispersal is limited to a few meters around the parental plants. Even in the case of some large macroalgae, such

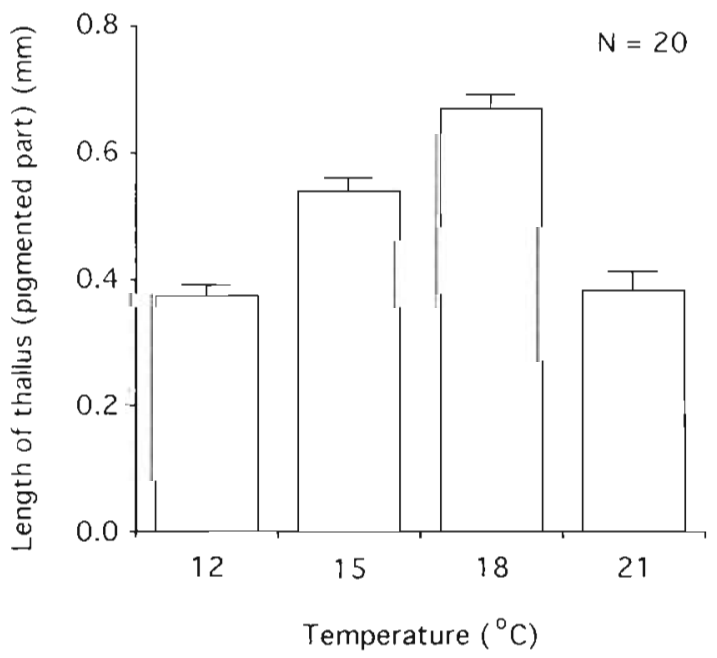

Fig. 10. Fucus serratus. Final size of embryos cultivated in the laboratory at 4 different temperatures. Only the pigmented part of the embryos was measured as Macrocystis pyrilera, in which dispersal can be initially thought to be effective, recruitment occurs within a mere $4 \mathrm{~m}$ radius from isolated parental plants (Anderson \& North 1966, Reed et al, 1988), although episodic, long-range dispersal also occurs in this species (Reed et al. 1988). More efficient dispersal occurs in mature floating algae, among others, this has been reported for Fucus vesiculosus, F. spiralis, Cystoseira spp., Halidrys siliquosa and Himanthalia elongata [Stegenga \& Mol 1983 (cited in van den Hoek 1987)]. A striking example is Sargassum muticum. While the dispersal ability of attached algae is limited, usually within $5 \mathrm{~m}$ from parentals (Deysher \& Norton 1982), mature floating specimens can disperse seedlings over enormous distances (Norton 1977b, Deysher \& Norton 1982). F. serratus, however, cannot float and this was invoked to explain the absence of the species from shores where it was expected to occur, such as the Faeroe Is. [Borgesen 1908 (cited in van den Hoek 1987)].

Competition with Fucus vesiculosus and perhaps Bifurcaria bifurcata and Mastocarpus stellatus may be occurring in the transition zone and beyond the distributional boundary. Within the normal range of distribution of $F$. serratus, $F$. vesiculosus and $B$. bifurcata occur above and below, respectively, the tidal level occupied by $F$. serratus, while $M$. stellatus is almost absent. At Oleiros, where F. serratus is absent, $F$, vesiculosus occurs lower on the shore, $B$. bifurcata higher, and $M$. stellatus appears at mid-tidal levels. Collectively they replace $F$. serratus on this shore. The outcome of competition might be different depending on the nature of the environment. In those zones where the physical environment is favourable for F. serratus, this alga would be the superior competitor, while in unfavourable locations it would be outcompeted by other

Table 5. Fucus serratus. Analyses of mean size of embryos after $26 \mathrm{~d}$ of incubation at $12,15,18$ and $21^{\circ} \mathrm{C}$. Variances were homogeneous (Cochran's test, p>0.05). Data are in Fig. 10. The analysis was made on the untransformed arbitrary measurement units of the microscope eyepiece

\begin{tabular}{lcrc|}
\hline $\begin{array}{l}\text { ANOVA } \\
\text { Source of variation }\end{array}$ & df & MS & $F$ \\
\hline Temperature & 3 & 397583.12 & $48.28^{\cdots}$ \\
Dish (T) & 12 & 8590.62 & $1.94^{\circ}$ \\
Residual & 64 & 4425.36 & \\
SNK tests $(=$ denotes not significantly different, $\mathrm{p}>0.05):$ \\
$18^{\circ} \mathrm{C}>15^{\circ} \mathrm{C}>12^{\circ} \mathrm{C}=21^{\circ} \mathrm{C}$ \\
$\mathrm{p}<0.05, \cdots \mathrm{p}<0.001$ \\
\end{tabular}


macroalgae. Competition between F. serratus and $F$. vesiculosus is important in determining the distribution of both algae in the tidal range (Schonbeck \& Norton 1980). Based on phytosociological associations, competition with $F$. edentatus has been invoked to limit the spread of $F$. serratus in Nova Scotia (Dale 1982). Pazó \& Niell (1977) concluded from observational studies that the distribution of $F$. serratus on the Atlantic coast of northwestern Spain is influenced by competition with $F$. vesiculosus. To my knowledge, however, no experiments have been done investigating the role of competition in setting the geographic limits of distribution of macroalgae.

There is evidence that the location of the boundary for some species has changed during this century. For instance, Sauvageau (1897) (cited in Fischer-Piette 1957) reported the presence of Fucus serratus in San Vicente, some $250 \mathrm{~km}$ east of Torbas. Later, Miranda (1931) indicated the presence of this species and other 'northern species' in Gijón (about $125 \mathrm{~km}$ east of Torbas). Fischer-Piette (1957) located the boundary in the region of Torbas. More recently, Anadón \& Niell (1981) and Anadón (1983) did not find F. serratus $25 \mathrm{~km}$ east of Torbas, while in this paper, the presence of $F$. serratus is reported in Novellana $(50 \mathrm{~km}$ east of Torbas) and Luanco (115 km east of Torbas), in the latter as a small isolated population. In Luanco F. serratus was absent $10 \mathrm{yr}$ ago (pers. obs.). The most feasible explanation for this is that the patterns of distribution are influenced by medium-term variations of climate or by fluctuating intensity of the upwelling events. Upwelling conditions depend upon the continuity of northeasterly winds during summer (Botas et al. 1990). Thus, important variations can be observed in temperature, even on a weekly basis (SATMER $1990 b, c)$. Variations in the wind regime also occur on a yearly basis (Gijón Weather Station unpubl. data). Changes in the environmental conditions (weather or oceanographic features) could, in turn, influence the outcome of interspecific relationships (e.g. competition). In benign or average years, F. serratus might survive and reproduce beyond its distributional boundary and colonize new localities. The boundary would displace to the east. Massive mortality of Fucus serratus plants should be expected in marginal localities in extreme years (e.g. exceptionally hot summers), thus limiting the spread of the species. In this case the boundary would move to the west.

In conclusion, the evidence presented here suggests that while temperature may be important in setting the large-scale distributional limits of Fucus serratus and can be used to explain the absence from the inner part of the Bay of Biscay, it cannot, alone, explain the present limit of distribution. When transplanted beyond that boundary, plants survive and reproduce success- fully. However, data for longer periods of time are necessary to assess the importance of extremely adverse years in the survival of $F$. serratus populations in marginal localities. Variation in the environmental conditions, low dispersal range and competition with other macroalgae probably act in conjunction with physical factors in shaping the present boundaries of F. serratus.

Acknowledgements. I am very grateful to R. M. Viejo L. Gutiérrez, R. Anadón, A. Bode and L. Diaz for help in the field. I thank Prof. B. Santelices for advice in the design of the experiments. Comments and corrections from Dr N. L. Andrew considerably improved the manuscript. Comments by Prof. C. van den Hoek are greatly appreciated. Corrections of 2 anonymous referees are acknowledged. The work was done under the tenure of a PFPI postdoctoral fellowship.

\section{LITERATURE CITED}

Anadón, R. (1983). Zonación en la costa asturiana: variación longitudinal de las comunidades de macrófitos en diferentes niveles de marea. Invest. pesq. 47: 125-141

Anadón, R., Niell, F X. (1981). Distribución longitudinal de macrótitos en la costa asturiana ( $N$ de España). Invest. pesq. 45: 143-156

Anderson, E. K., North, W. J. (1966). In-situ studies of spore production and dispersal in the giant kelp Macrocystis. Proc. int. Seaweed Symp. 5: 73-86

Bird, C. J., McLachlan, J. (1986). The effect of salinity on distribution of species of Gracilaria Grev. (Rhodophyta, Gigartinales): an experimental assessment. Botanica mar. 29: $231-238$

Botas, J. A., Fernández, E., Bode, A., Anadón, R. (1990). A persistent upwelling off the Central Cantabrian Coast (Bay of Biscay). Estuar. coast. Shelf Sci. 30: 185-199

Breeman. A. M. (1988). Relative importance of temperature and other factors in determining geographic boundaries of seaweeds: experimental and phenological evidence. Helgoländer Meeresunters. 42: 199-241

Cambridge, M. L., Breeman, A. M., van den Hoek, C. (1990). Temperature limits at the distribution boundary of four tropical to temperate species of Cladophora (Cladophorales: Chlorophyta) in the North Atlantic Ocean. Aquat. Bot. 38: 135-151

Chapman, A. R. O. (1986). Population and community ecology of seaweeds. Adv. mar. Res. 23: 1-161

Chapman, A. R. O., Craigie, J. S. (1977). Seasonal growth in Laminaria longicruris: relations with dissolved inorganic nutrients and internal reserves of nitrogen. Mar. Biol. 40: $197-205$

Dale, M. (1982). Phytosociological structure of seaweed communities and the invasion of Fucus serratus in Nova Scotia. Can. J. Bot. 60: 2652-2658

Dayton, P. K. (1973). Dispersion, dispersal, and persistence of the annual intertidal alga, Postelsia palmaeformis Ruprecht. Ecology 54: 433-438

DeBoer, J. A. (1981). Nutrients. In: Lobban, C. S., Wynne, M. J (eds.) The biology of seaweeds. Blackwell Scientific Publications, Oxford, p. 356-392

Deysher, L., Norton, T A. (1981). Dispersal and colonization of Sargassum muticum (Yendo) Fensholt. J. exp. mar. Biol. Ecol. 56: 179-195 
Dring, M. J. (1982). The biology of marine plants. Edward Arnold Ltd, London

Fischer-Piette, E. (1957). Sur des déplacements de frontières biogéographiques, observés au long des còtes ibériques dans le domaine intercotidal. Publnes Inst. Biol. apl., Barcelona 26: 35-40

Gaines, S. D., Lubchenco, J. (1982). A unified approach to marine plant-herbivore interactions. II. Biogeography. A. Rev. Ecol. Syst. 13: 111-138

Grashoff, K. (1983). Determination of nitrate. In: Grashoff, K., Ehrhardt, M., Kremling, K. (eds.) Methods of seawater analysis. Verlag Chemie, Weinheim

Hay, M. E. (1981). Herbivory, algal distribution, and the maintenance of between-habitat diversity on a tropical fringing reef. Am. Nat. 118: 520-540

Lobban, C. S., Harrison, P. J., Duncan, M. J. (1985). The physiological ecology of seaweeds. Cambridge Univ. Press, Cambridge

Lubchenco, J. (1980). Algal zonation in the New England rocky intertidal community: an experimental analysis. Ecology 61: 333-344

Lüning, K. (1990). Seaweeds. Their environment, biogeography, and ecophysiology. John Wiley \& Sons, New York

Maillard, C. (1986). Atlas hydrologique de l'Atlantique NordEst. Institut Français de Recherche pour l'Exploitation de la Mer, Brest

McLachlan, J. (1973). Growth media. Marine. In: Stein, J. R. (ed.) Handbook of phycological methods: culture methods and growth measurements. Cambridge Univ. Press, Cambridge, p. 25-51

McLachlan, J., Chen, L. C. M., Edelstein, T (1971). The culture of four species of Fucus under laboratory conditions. Can. J. Bot. 49: 1463-1469

Miranda, F. (1931). Sobre las algas y cianofíceas del Cantábrico, especiaimente de Gijón. Trab. Mus. nac. Cienc. nat., Ser, bot., Madrid 25: 1-106

Norton, T. A. (1977a). Experiments on the factors influencing the geographical distributions of Saccorhiza polyschides and Saccorhiza dermatodea. New Phytol. 78: 624-635

Norton, T A. (1977b). The growth and development of Sargassum muticum. J. exp. mar. Biol. Ecol. 26: 41-53

Paine, R. T. (1979). Disaster, catastrophe, and local persistence of the sea palm Postelsia palmaeformis. Science 205: 685-686

Pazó, J. P., Niell, F. X. (1977). Distribución y características de Fucus serratus L en las Rías Bajas Gallegas. Invest. pesq. 41: $455-472$

This article was submitted to the editor
Reed, D. C., Laur, D. R., Ebeling, A. W. (1988). Variation in algal dispersal and recruitment: the importance of episodic events. Ecol. Monogr. 58: 321-335

Russell, G. (1987). Spatial and environmental components of evolutionary change: interactive effects of salinity and temperature on Fucus vesiculosus as an example. Helgoländer Meeresunters. 41: 371-376

Santelices, B. (1990). Patterns of reproduction, dispersal and recruitment in seaweeds. Oceanogr. mar. Biol. A. Rev. 28 $177-276$

SATMER (1990a). SATMER: a monthly bulletin of oceanographic data obtained from weather satellites, no. 37. January 1990. Centre de Meteologie Spatiale, Lannion, France (English translation by Pharos Scientific Ltd)

SATMER (1990b). SATMER: a monthly bulletin of oceanographic data obtained from weather satellites, no. 43. July 1990. Centre de Meteologie Spatiale, Lannion, France (English translation by Pharos Scientific Ltd)

SATMER (1990c). SATMER: a monthly bulletin of oceanographic data obtained from weather satellites, no, 44 August 1990. Centre de Meteologie Spatiale, Lannion, France (English translation by Pharos Scientific Ltd)

Schonbeck, M., Norton, T. A. (1980). Factors controlling the lower limits of fucoid algae on the shore. J. exp. mar. Biol. Ecol. 43: 131-150

US Naval Oceanographic Office (1967). Oceanographic atlas of the North Atlantic Ocean. Section II. Physical properties. US Naval Oceanographic Office, Washington, DC, Publication no. 700

van den Hoek, C. (1975). Phytogeographic provinces along the coasts of the northern Atlantic Ocean. Phycologia 14: $317-330$

van den Hoek, C. (1982). The distribution of benthic marine algae in relation to the temperature regulation of their life histories. Biol. J. Linn. Soc. 18: 81-144

van den Hoek, C. (1987). The possible significance of longrange dispersal for the biogeography of seaweeds. Helgoländer Meeresunters. 41: 261-272

Wheeler, P. A., North, W. J. (1980). Effect of nitrogen supply on nitrogen content and growth rate of juvenile Macrocystis pyrifera (Phaeophyta) sporophytes. J. Phycol. 16: $577-582$

Yarish, C., Kirkman, H., Lüning, K. (1987). Lethal exposure times and preconditioning to upper temperature limits of some temperate North Atlantic red algae. Helgoländer Meeresunters. 41:323-327

Manuscript first received: June 1, 1992

Revised version accepted: November 16, 1992 